\title{
Characteristics, Nutritional Status, and Blood Sugar Levels of Type 2 Diabetes Mellitus with Mediteranian Diet
}

\author{
Endry Septiadi* \\ Department of Nutrition, Faculty of Medicine \\ University of Jenderal Achmad Yani \\ Cimahi, Indonesia \\ *endry.septiadi@lecture.unjani.ac.id
}

\author{
Iis Inayati Rakhmat, Dewi Ratih Handayani \\ Department of Biochemistry, Faculty of Medicine \\ University of Jenderal Achmad Yani \\ Cimahi, Indonesia
}

\author{
Reza Fadhil Nugraha, M. Arasy Faradina, Nur Muhamad Rohman, Muhammad Akmal Rais \\ General Medicine Study Program, Faculty of Medicine \\ University of Jenderal Achmad Yani \\ Cimahi, Indonesia
}

\begin{abstract}
Type 2 diabetes mellitus (Type 2 DM) is a metabolic disease due to disorders of the pancreas in producing insulin. Poor diet can cause abnormal blood sugar levels. The Mediterranean diet is a diet that is recommended for people with type 2 DM because it contains unsaturated fatty acids (MUFA and PUFA), high antioxidants, and low glycemic index that can improve nutritional status and blood sugar levels. This study aims to describe the characteristics, nutritional status, and blood sugar levels of type $2 \mathrm{DM}$ patients with a Mediterranean diet in a clinic that has Prolanis in Bandung. The research method used is descriptive with a cross-sectional design. The sample size was 24 patients with type $2 \mathrm{DM}$ on the Mediterranean diet for one month. Sampling was done by consecutive sampling. Subject characteristics include age, gender, and level of education. The nutritional status examined included Body Mass Index (BMI) and waist circumference. The blood sugar levels checked in this study were fasting blood sugar levels. Most of the subjects were women with a mean age of $\mathbf{5 5 . 2 1}$ years and high school education level. Nutritional status based on BMI was obtained, namely obesity I, waist circumference obtained by female patients having a waist circumference $>80 \mathrm{~cm}$ and men having a waist circumference $>90 \mathrm{~cm}$. The average fasting blood sugar levels were $149.67 \mathrm{mg} / \mathrm{dl}$. The effect of the Mediterranean diet on type 2 diabetes patients shows that the mean fasting blood sugar levels and nutritional status have not reached normal values.
\end{abstract}

Keywords-fasting blood sugar, Mediterranean Diet, Nutritional status, Type 2 diabetes mellitus

\section{INTRODUCTION}

Diabetes mellitus (DM) consists of type 1 DM or Insulin Dependent Diabetes Mellitus (IDDM) and type 2 DM or NonInsulin Dependent Diabetes Mellitus (NIDDM). The pathophysiology of type 1 diabetes is related to decreased insulin production, while type 2 diabetes is a metabolic disease due to disorders of the pancreas in producing insulin and the presence of insulin resistance in muscles $[1,2]$. The prevalence of DM in the world is based on World Health Organization (WHO) data in 2015 amounted to 415 million adults with diabetes. The percentage of adults with diabetes in 2015 was $8.5 \%$ or one in eleven adults was affected by diabetes [3]. Based on the results of the Basic Health Research (RISKESDAS) in 2013, the prevalence of DM in Indonesia increased from $5.7 \%$ in 2007 to $6.9 \%$ or about 9.1 million in 2013 [4]

Type 2 diabetes mellitus is caused by several factors. Nonmodifiable risk factors such as age, gender and genetics. Modifiable risk factors such as diet, resting patterns, daily life patterns of activity, and stress management [5]. Characteristics of type 2 diabetes mellitus based on age are very influential in increasing blood sugar levels, especially those over 40 years of age. This is due to changes in lifestyle such as lack of activity and changes in unbalanced eating patterns, besides changes in physiology, anatomy and biochemistry of the body [6,7]. Type 2 diabetes is more common in women than men, this happens because of the existence of changes in body physiology, anatomy and biochemistry. Differences in the amount of sexual hormones and differences in body fat composition [6,8]. The level of education is indirectly related to understanding of type 2 diabetes so that it increases self-awareness of type 2 diabetes mellitus treatment [2,6,9]. Body mass index (BMI) is very influential on type 2 diabetes mellitus. excess risk of insulin resistance due to excess fat. Insulin resistance can result in increased blood glucose levels. This situation causes the pancreas to be unable to produce insulin as needed and can 
result in excess glucose production in the liver which causes blood glucose levels to increase [10,11].

Management of type 2 diabetes mellitus includes four pillars, namely nutritional therapy, physical activity, education, and pharmacology [12-15]. Pharmacological therapy in the form of oral anti-diabetic therapy with indications that nonpharmacological therapy has been given for 4-8 weeks without a decrease in fasting glucose levels $>126 \mathrm{mg} / \mathrm{dl}$ and HbA1c > $6.5 \%$. The type of drug that is often used in Indonesia according to the Diabetes Prevention Program (DPP) is metformin [16,17]. A diet high in carbohydrates and high in saturated fat will cause the progression of type 2 diabetes mellitus to accelerate. Individuals with diabetes should be encouraged to replace refined carbohydrates and add vegetables, fruit, nuts, or seeds. Several studies have reported that a Mediterranean diet rich in unsaturated fats can control blood sugar levels [18]. The Mediterranean diet is a diet characterized by high consumption of vegetables, nuts, seeds, fruits, and olive oil which contains acids. high $\alpha$-linolenic acid, consumption of fish, wine, and low consumption of processed meats and fatty dairy products. Results from a prospective study from Southern Europe showed a lower incidence of DM with adherence to the Mediterranean diet. The Mediterranean diet shows better glycemic control and reduces the need for treatment with antidiabetic drugs in type 2 [19-21].

Diabetes mellitus is a chronic metabolic disorder caused by insufficient insulin production or the ineffective use of insulin in the body. In 2013, there were about 9.1 million people in Indonesia diagnosed with type 2 diabetes and an increase every year. Type 2 diabetes mellitus is influenced by several factors such as gender, age, education level and unbalanced diet. One of the nutritional therapy for type 2 diabetes mellitus is the Mediterranean diet which contains high levels of antioxidants and unsaturated fatty acids such as Monounsaturated Fatty Acid (MUFA) and Polyunsaturated Fatty Acid (PUFA) which can prevent damage to the endothelium of blood vessels and thus prevent complications. This study aims to describe the characteristics, nutritional status, and blood sugar levels of people with diabetes type 2 with a Mediterranean diet [1,3$5,13,19,22]$.

\section{METHODS}

This study is a descriptive study with a cross-sectional design in type 2 diabetes mellitus sufferers with Mediterranean diet for one month. Subjects who did a Mediterranean diet were identified using a questionnaire, namely the Mediterranean Diet Score (MDS).

In this study, 24 patients with type 2 diabetes with a Mediterranean diet were found. Sampling in this study was carried out by consecutive sampling. Sampling was done by taking the subject's blood intravenously, then checking the subject's fasting blood sugar level in the laboratory, and assessing the nutritional status by conducting an anthropometric examination to determine BMI and measuring the waist circumference of people with type 2 diabetes mellitus on the Mediterranean diet.

This research was conducted after the research subjects were available and filled out the informed consent form which was previously explained by the researcher regarding the aims and objectives of the study, the procedure for the examination, the benefits of the research, the possibility of inconvenience during the research procedure, and the confidentiality of data to the research subjects.

Descriptive analysis was performed to determine the mean, standard deviation, minimum and maximum values of fasting blood sugar using SPSS version 21.0

\section{RESULTS AND DISCUSSION}

\section{A. Number of Type 2 DM Patients on a Mediterranean Diet}

Based on the results of the study, there were 24 out of 30 type $2 \mathrm{DM}$ patients who were running a Mediterranean diet or $80 \%$.

Type 2 DM patients with Mediterranean diet are classified as low in consuming olive oil which contains high $\alpha$-linolenic acid because it is difficult to obtain and the price is relatively expensive. Patients consume more vegetables, fruits, whole grains, nuts, fish consumption, and avoid processed meats and high-sugar foods. This is consistent with the characteristics of the Mediterranean diet

As many as $20 \%$ of the study subjects did not apply the Mediterranean diet for several reasons such as disliking vegetables, disliking fruits, difficulty obtaining olive oil due to high costs, unruly diet, and high consumption of red meat.

\section{B. Age of Type 2 DM Patients with a Mediterranean Diet}

Based on the results of the study, the average age of the patients was 55.21 years (95\% CI: 50.98 - 59.44). The youngest age of the patient was 37 years and the oldest age was 78 years.

The results are in accordance with the research of Suroika, 2012 which states that the average age of type 2 DM sufferers is 40 years. According to WHO, at the age of 30, there was an increase in blood sugar levels of 1-2 mg/dl/ year during fasting, and an increase of $5.6-13 \mathrm{mg} / \mathrm{dl}$ at 2 hours after eating. At the age after 40 years, there are physiological, anatomical, and biochemical changes in the body, especially a decrease in insulin production by $\beta$ cells for glucose metabolism $[6,7]$.

The main sources of fat in the Mediterranean diet are MUFAs and PUFAs which are very well applied to type 2 DM patients to reduce blood sugar levels. An inactive lifestyle accompanied by poor diet in old age requires control of food intake to maintain the quality of life. Based on research conducted by Karam J, 2019, the quality of life of patients with metabolic syndrome aged 55-70 years with good compliance with the Mediterranean diet has a good quality of life [6,2325]. 


\section{Gender of Type 2 DM Patients with a Mediterranean Diet}

The results showed that most of the Prolanis patients were female as many as 17 people (71\%), while as many as 7 men (29\%).

The results of the study are in accordance with the results of Prasetyani's research, 2011 which states that the dominant type 2 diabetes sufferer is female. The main cause of type 2 diabetes mellitus in women is decreased levels of the hormone estrogen so that body fat reserves in the abdominal area increase which results in high levels of $\mathrm{HbAlc}$ in women who have experienced menopause [6,8].

Based on research conducted by Karam J, 2019 women have a better level of adherence to the Mediterranean diet than men. A significant difference is the amount of consumption of unsaturated fats (MUFA and PUFA) which is more than saturated fat [25].

\section{Educational Level of Type 2 DM Patients with a Mediterranean Diet}

This research shows that the education level of elementary school $(29 \%)$ and junior high school $(29 \%)$ is the majority. Higher education levels are easier to understand about the Mediterranean diet presented by researchers. The results of the study are in line with Maria del Mar's study, 2017 that a person with a higher level of education has a good level of adherence to the Mediterranean diet [26].

Motivating type $2 \mathrm{DM}$ patients to carry out a Mediterranean diet through appropriate educational methods is very important. The majority of type $2 \mathrm{DM}$ patients in this study had a good level of adherence in following the Mediterranean diet because each research subject had received socialization about the importance of the Mediterranean diet as a nutritional therapy in an effort to control blood sugar levels, but patients still need adaptations to change their dietary patterns in daily meals $[6,9,27]$.

\section{E. Body Mass Index (BMI) of Type 2 DM Patients with a Mediterranean Diet}

Based on this study, it can be seen that the subject has BMI with a classification of 1 overweight patient, 11 obese I patients, and 4 obese II patients. Subjects who have ideal body weight are 6 people and underweight are 2 people. The nutritional status of type 2 DM patients with a Mediterranean diet in BMI is shown in Table 1.

Excess body mass index is closely related to insulin resistance. Accumulation of fat in tissues can interfere with insulin resistance, thereby inhibiting the absorption of glucose and fat cells into muscles so that blood sugar increases. This situation causes the pancreas to be unable to produce insulin as needed. Pancreatic $\beta$ cells have a function to regulate insulin secretion so that glucose levels in the body are balanced. Type 2 diabetes mellitus experiences pancreatic $\beta$ cell failure which results in decreased insulin levels. Insulin resistance results in gluconeogenesis resulting in an increase in glucose production in the liver $[5,11,28]$.

TABLE I. BODY MASS INDEX TYPE 2 DM PATIENT WITH MEDITERRANEAN DIET

\begin{tabular}{|c|c|c|}
\hline \multirow{2}{*}{ BMI } & $\mathbf{n}$ & \multirow{2}{*}{$\%$} \\
\hline & Mediterranean diet & \\
\hline $17,0-<18,5=$ Underweight & 2 & 8,3 \\
\hline $18,5-<23=$ Normal & 6 & 25 \\
\hline $23-<25=$ Overweight & 1 & 4,2 \\
\hline $25-<30=$ Obesity I & 11 & 45,8 \\
\hline$>30=$ Obesity II & 4 & 16,7 \\
\hline Total & 24 & 100 \\
\hline
\end{tabular}

Based on Muscogiuri's research, 2019 it is known that consumption of the Mediterranean diet in obese people has an effect on reducing body fat levels. The characteristics of the Mediterranean diet are the consumption of high antioxidant foods such as vegetables, fruits, and the replacement of saturated fatty acid (SAFA) consumption with unsaturated fats such as PUFA and MUFA has been shown to control body fat levels so that body weight decreases, blood sugar levels are controlled. prevents insulin resistance, and endothelial inflammation $[19,29]$.

In this study, it was found that the average patient experienced Obesity 1 because of a positive energy imbalance, namely excess calorie intake is not balanced with calorie burning so that body weight increases [30]. The results are not in line with the research of Fernandez, 2012 who carried out a Mediterranean diet for three months, obtained weight loss approximately $9 \mathrm{~kg}$ and a BMI of $4 \mathrm{~kg} / \mathrm{m} 2$. It is based on restricting $40 \%$ of the usual energy intake $(500 \mathrm{kcal} / \mathrm{day}$; where $1 \mathrm{kcal}=4,168 \mathrm{~kJ}$ ) for weight loss. This calorie restriction will lead to weight loss, thereby reducing the risk of obesity [3133].

\section{F. Waist Circumference of Type 2 DM Patients with a Mediterranean Diet}

The results obtained in female patients with a waist circumference $\leq 80 \mathrm{~cm}$ were 4 people $(16.7 \%)$ and female patients with a waist circumference $>80 \mathrm{~cm}$ were 13 people $(54.2 \%)$. There were 3 male patients with a waist circumference $\leq 90 \mathrm{~cm}(12.5 \%)$ and 4 male patients with a waist circumference> $90 \mathrm{~cm}(16.7 \%)$. The research results can be seen in Table 2 below. Excess waist circumference results in an increase in fatty acids or Free Fatty Acid (FFA) in cells which causes a decrease in glucose uptake to the plasma membrane and insulin resistance in adipose tissue and muscle $[10,11,28]$. See table 2 below. 
TABLE II. WAIST CIRCUMFERENCE OF TYPE 2 DM PATIENTS WITH A MEDITERRANEAN DIET

\begin{tabular}{|c|c|c|}
\hline \multirow{2}{*}{ Waist circumference } & $\mathbf{n}$ & \multirow{2}{*}{$\%$} \\
\hline & Mediterranean diet & \\
\hline Women $\leq 80 \mathrm{~cm}$ & ( & 16,7 \\
\hline Women $>80 \mathrm{~cm}$ & 13 & 54,2 \\
\hline Men $\leq 90 \mathrm{~cm}$ & 3 & 12,5 \\
\hline Men $>90 \mathrm{~cm}$ & 4 & 16,7 \\
\hline Total & 24 & 100 \\
\hline
\end{tabular}

In this study the majority of subjects had excess waist circumference. The length of time applying the Mediterranean diet and lack of physical activity greatly affects waist circumference. The results of the study are not in line with the research of Salcin, 2019 that in subjects who did a Mediterranean diet for four weeks, there was weight loss and reduced visceral fat in the body. This is because it is balanced by good physical activity with a high level of adherence to a Mediterranean diet. In addition, the ideal time to reduce visceral fat levels according to research conducted by Fernandez, 2012 is three months because a decrease in calories per day (500 kcal / day) and physical activity can reduce waist circumference by approximately $7 \mathrm{~cm}$ in three months of consuming the Mediterranean diet. along with physical activity $[33,34]$.

\section{G. Fasting Blood Sugar Levels in Type 2 DM Patients}

The results showed that the average fasting blood sugar level of type $2 \mathrm{DM}$ patients with a Mediterranean diet was $149.67 \mathrm{mg} / \mathrm{dl}$ (95\% CI: 50.98 - 59.44) with a standard deviation of 54.962. The patient's lowest blood sugar level was $80 \mathrm{mg} / \mathrm{dl}$ and the highest was $305 \mathrm{mg} / \mathrm{dl}$.

The results of research conducted by Al Jamal AR and Ibrahim A, 2011 showed that olive oil can reduce fasting blood sugar levels in people with type 2 diabetes after four weeks of consuming olive oil. Olive oil contains PUFA omega 3, PUFA omega 6, and MUFA which play a role in increasing the secretion of hepatic enzymes catalase, superoxidase dismutase, and glutathione peroxidase which are high in antioxidants, antiinflammatory and hypolipidemic in nature so they can prevent decreased insulin sensitivity in target cells and obesity [35-38].

The average blood sugar level of the study subjects was $149.67 \mathrm{mg} / \mathrm{dl}$, which is not in line with the study of Salcin, 2019 which states that there is a decrease in fasting blood sugar levels in type $2 \mathrm{DM}$ patients who apply the Mediterranean diet for four weeks. Several factors influenced the persistence of high blood sugar levels in most of the subjects in this study, such as less subjects who consumed olive oil and lack of physical activity. Another factor is that most of the subject's work and are given food by the workplace with a food menu provided by the company so that they are not consistent in carrying out a Mediterranean diet.

The length of time the diet affects the decrease in blood sugar levels. Research conducted by Cariello A, 2014, ideally the length of application of the Mediterranean diet is three months. Several studies had controlled blood sugar levels following a Mediterranean diet with consuming lots of fruits and vegetables as a high source of antioxidants despite the limited consumption of olive oil. Consumption of fruits and vegetables increases the antioxidant capacity of plasma which is useful for increasing anti-inflammatory cytokines thus preventing insulin resistance and improving basal endothelial function $[19,36]$.

\section{H. Limitation}

The limitation in this study is that the Mediterranean diet which is applied for one month is difficult to obtain the results using the $24 \mathrm{~h}$ food recall so that the patient's daily menu in detail is not known. Patient adherence to the Mediterranean diet has been difficult to monitor for investigators. Another limitation of this study is the level of knowledge of the patients who differ according to their education level and the lack of patients consuming olive oil due to the high cost and the large number of patients who work so they tend to eat less at work. Another limitation is that the researchers did not make a detailed daily menu for the Mediterranean diet regarding the portions of food that should be consumed.

\section{CONCLUSION}

The number of type $2 \mathrm{DM}$ patients with the Mediterranean diet in this study was 24 out of 30 patients with type 2 diabetes who were obtained $(80 \%)$. The average age of the study subjects with the Mediterranean diet was 55.21 years. The majority of study subjects were female, with low education level, BMI $>25 \mathrm{~kg} / \mathrm{m} 2$ (obesity level 1 ), and had a waist circumference of $>80 \mathrm{~cm}$ in women while a normal waist circumference was $\leq 90 \mathrm{~cm}$ in men. The average fasting blood sugar level in type $2 \mathrm{DM}$ patients who applied the Mediterranean diet was $149.67 \mathrm{mg} / \mathrm{dl}$.

\section{ACKNOWLEDGMENT}

Thanks are given to the Institute for Research and Community Service (LPPM) Jenderal Achmad Yani University for providing grant funding for this research.

\section{REFERENCES}

[1] KEMENKES, “Kenali Kebiasaan Penyebab Diabetes.” 2018, pp. 20-1.

[2] PERKENI, Indonesia P E "Pengelolaan dan Pencegahan Diabetes Melitus Tipe 2 di Indonesia." PB. PERKEN, 2015.

[3] World Health Organization. Epidemiological Situation, 2016.

[4] Riset Kesehatan Dasar Kementerian RI, Proceedings, Annu Meet - Air Pollut Control Assoc. vol. 6, 2013.

[5] N. Isnaini and R. Ratnasari, "Faktor Risiko Mempengaruhi Kejadian Diabetes Mellitus Tipe 2." J Kebidanan dan Keperawatan Aisyiyah, vol. 14, pp. 59-68, 2018

[6] D. Prasetyani and E. Apriani, "Karakteristik Pasien Diabetes Melitus Tipe 2 di Puskesmas Cilacap Tengah 1 dan 2," pp. 42-9, 2011

[7] G.S.N. Iroth, G.D. Kandou, and N.S.H. Malonda, "Hubungan Antara Umur dan Pola Makan dengan Kejadian Diabetes Mellitus Tipe 2 pada 
Pasien Rawat Jalan di Wilayah Kerja Puskesmas di Sulawesi Utara." vol. 887, 2013.

[8] R. Yosmar, D. Almasdy, and F. Rahma "Survei Risiko Penyakit Diabetes Melitus Terhadap Masyarakat Kota Padang." Sains Farm dan Klin, vol. 5, pp. 134-41, 2018

[9] A.N. Kistianita and R.W. Gayatri, "Analisis Faktor Risiko Diabetes Mellitus Tipe 2 Pada Usia Produktif Dengan Pendekatan Who Stepwise Step 1 (Core / Inti) di Puskesmas Kendalkerep Kota Malang." Prev Indones J Public Heal, vol. 3, no. 1, pp. 1-14, 2018.

[10] A.P. Astiti and M.P. Dwipayana, "Hubungan indeks massa tubuh (IMT) dengan kadar gula darah puasa pada siswa sekolah menengah atas (SMA) Negeri di wilayah Denpasar Utara." E-Jurnal Med Udayana, vol. 7, no. , pp. 95-8, 2018

[11] A. Fadilah, Y. Putri, E. Decroli, and E. Nasrul, "Hubungan Derajat Obesitas dengan Kadar Gula Darah Puasa. Artikel Penelitian." J Kesehat Andalas, vol. 4, no. 3, pp. 707-11, 2015.

[12] I.W.A. Putra and K.N. Berawi, "Empat Pilar Penatalaksanaan Pasien Diabetes Mellitus Tipe 2." Majority, vol.4, no. 9, pp. 8-12, 2015.

[13] N.H.K. Putri and M.A. Isfandiari, "Hubungan Empat Pilar Pengendalian DM Tipe 2 dengan Rerata Kadar Gula Darah." J Epidemiol., vol. 1, no. 2, pp. 234-43, 2013.

[14] S. Susanti and D.N. Bistara, Hubungan Pola Makan Dengan Kadar Gula Darah Pada Penderita Diabetes Mellitus." J Kesehat Vokasional, vol. 3, no. 1, p. 29, 2018.

[15] P. Eryna Laily, "Hubungan antara latihan jasmani dengan kadar glukosa darah penderita diabetes." J Berk Epidemio,.vol. 4, pp. 188-99, 2016.

[16] F.D. Sari, Inayah, and M.Y. Hamidy, "Pola Penggunaan Obat Anti Hiperglikemik Oral pada Pasien Diabetes Melitus Tipe 2.” Jom FK. ,vol. 3 , no. $1,2016$.

[17] R.N. Fatimah, "Diabetes Mellitus Tipe 2." Indones J Pharm., vol. 27, no. 2, p. 74

[18] American Diabetes Association. "Standards of Medical Care in Diabetes." vol. 39, 2016

[19] Z. Labibah, D.I. Anggraini, M.P. Dokter, F. Kedokteran, LU. ampung U, and B.I. Gizi,. "Diet Mediterania dan Manfaatnya terhadap Kesehatan Jantung dan Kardiovaskular.” vol. 5, 2016.

[20] J. Salas-Salvadó, M. Bulló, and N. Babio, "Reduction in the incidence of type 2 diabetes with the Mediterranean diet: results of the PREDIMEDReus nutrition intervention randomized trial." Diabetes Care, 2011.

[21] K. Esposito, M.I. Maiorino, and M. Ciotola, "Effects of a Mediterranean-style diet on the need for antihyperglycemic drug therapy in patients with newly diagnosed type 2 diabetes: a randomized trial." Ann Intern Med, vol. 151, pp. 306-314, 2009.

[22] M. Vitale, M. Masulli, and I. Calabrese, "Impact of a mediterranean dietary pattern and its components on cardiovascular risk factors, glucose control, and body weight in people with type 2 diabetes: A reallife study." Nutrients, vol. 10, no. 8, 2018.

[23] I. Galilea-Zabalza, P. Buil-Cosiales, J. Salas-Salvadó, E. Toledo, C Ortega-Azorín, and J. Díez-Espino, "Mediterranean diet and quality of life: Baseline cross-sectional analysis of the PREDIMED-PLUS trial." PLoS One, vol. 13, no. 6, pp. 2017-9, 2018.
[24] T. Govindaraju, B.W. Sahle, T.A. McCaffrey, J.J. McNeil, and A.J. Owen, "Dietary patterns and quality of life in older adults: A systematic review." Nutrients, vol. 10, no. 8, pp. 1-18, 2018.

[25] J. Karam, M. M del M. Bibiloni, A. Pons, and J.A. Tur "Total fat and fatty acid intakes and food sources in Mediterranean older adults requires education to improve health." Nutr Res., vol. 73, pp. 67-74, 2020.

[26] M. Del Mar Bibiloni, M. González, A. Julibert, I. Llompart, A. Pons, and J.A. Tur, "Ten-year trends (1999-2010) of adherence to the mediterranean diet among the Balearic Islands' adult population." Nutrients, vol. 9, pp. 1-12, 2017

[27] N. Widyasari, "Hubungan Karakteristik Responden dengan Risiko Diabetes Melitus dan Dislipidemia Kelurahan Tanah Kalikedinding. FKM UNAIR.” pp. 130-141, 2017.

[28] W. Meidikayanti and C.U. Wahyuni, "Hubungan dukungan keluarga dengan kualitas hidup Diabetes Melitus Tipe 2 Di Puskesmas Pademawu." J Berk Epidemiol, vol. 5, pp. 240-52, 2017

[29] G. Muscogiuri, L. Barrea, D. Laudisio, C. Di Somma, G. Pugliese, and C. Salzano, "Somatotropic axis and obesity: Is there any role for the Mediterranean diet." Nutrients, vol. 11, pp. 1-15, 2019.

[30] M.K. Sari, N.I. Lipoeto, and R.B. Herman, "Artikel Penelitian Hubungan Lingkar Abdomen (Lingkar Perut) dengan Tekanan Darah.” J Kesehat Andalas, vol. 5, pp. 456-61, 2016

[31] G. Buckland, A. Bach, and L. Serra-Majem, "Obesity and the Mediterranean diet: A systematic review of observational and intervention studies." Obes Rev., vol. 9, pp. 582-93, 2008.

[32] S. D'innocenzo, C. Biagi, and M. Lanari, "Obesity and the mediterranean diet: A review of evidence of the role and sustainability of the mediterranean diet." Nutrients, vol. 11, 2019.

[33] J.M. Fernández, D. Rosado-Álvarez, M.E. Da Silva Grigoletto, O.A. Rangel-Zúñiga, L.L. Landaeta-Díaz, and J. Caballero-Villarraso, "Moderate to high intensity training and a hypocaloric Mediterranean diet enhance endothelial progenitor cells and fitness in subjects with the metabolic syndrome." Clin Sci., vol. 123, pp. 361-73, 2012.

[34] L.O. Salcin, Z. Karin, V.M. Damjanovic, M. Ostojic, A. Vrdoljak, and B. Gilic, "Physical activity, body mass, and adherence to the mediterranean diet in preschool children: A cross-sectional analysis in the split-dalmatia county (Croatia).” Int J Environ Res Public Health, vol. 16, 2019.

[35] K.K. Kaur, G. Allahbadia, and M. Singh, "Synthesis and Functional Significance of Poly Unsaturated Fatty Acids (PUFA's) in Body." Acta Sci Nutr Heal, vol. 2, no. 4, pp. 43-50, 2018.

[36] L. Schwingshackl and G. Hoffmann, "Monounsaturated fatty acids and risk of cardiovascular disease: Synopsis of the evidence available from systematic reviews and meta-analyses." Nutrients, vol. 4, no. 12, pp. 1989-2007, 2012

[37] J.S. Perona, R. Cabello-Moruno, and V. Ruiz-Gutierrez, "The Role of Virgin Olive Oil Components in the Modulation of Endothelial Function. (Internet)." J Nutr Biochem, vol. 17, pp. 429-445, 2006.

[38] A.R. Al Jamal and A. Ibrahim, "Effects of Olive Oil on Lipid Profiles and Blood Glucose in Type 2 Diabetic Patients." Int J Diabetes \& Metab, vol. 19, pp. 19-22, 2011. 